\title{
An evaluation of web enhanced instruction in college level biology courses
}

\author{
Tamar Keasar \\ Achva Academic College, Israel \\ Rachel Baruch and Esther Grobgeld-Dahan \\ Achva College of Education, Israel
}

\begin{abstract}
Websites that accompany science courses typically aim to provide easy access to learning materials, and to facilitate student-instructor communication. We tested whether these aims were achieved in two web enhanced, lower division undergraduate biology courses in an Israeli college. We collected data on the students' attitudes through pre- and postcourse questionnaires, monitored their usage of the course websites, and related these data to the students' final course grades.

The students $(n=96)$ accessed the websites frequently and regularly, and regarded them as important sources of information. About $47 \%$ of the students reported an increased level of general interest in the courses due to the websites. Students mainly downloaded lecture slides and exercise forms from the websites, but did not use the sites to communicate among themselves, or with the instructor. Final course grades were not correlated with the frequency of usage of the website. Female students had a more positive pre-course attitude towards the websites as compared with male students. However, there was no difference between men and women in usage of the course websites, and in achievement levels.
\end{abstract}

We conclude that the website component of the courses in our study facilitated delivery of learning materials and individual study, but not the social aspects of learning. We suggest that effective design of web enhanced courses can overcome this limitation by stressing social interactions and group learning during face to face sessions.

\section{Introduction}

The rapid advance of Internet technology is creating exciting opportunities and challenges for teachers at all levels (Bates, 1999; Levenberg \& Major, 1998; Schifter, 2000; Van Dusen, 1997). Web enhanced instruction has become standard practice in most institutions of higher learning in Western 
countries (Allen \& Seaman, 2003; Waits \& Lewis, 2003). Courses that are completely online are relatively rare, however, particularly in the natural sciences (US Department of Education, 1999). This tendency may be due to several reasons. First, many science courses include laboratories and/or field trips that cannot be easily replaced by distance learning. Secondly, these courses are typically very discipline oriented, and do not aim to train students in distance learning skills. Instructors may feel that spending time on teaching such skills is not a top priority in science courses. Finally, many instructors and administrators value the social interaction in learning communities, and believe that it cannot be adequately achieved though distance learning (Guri-Rosenblit, 2003). Therefore, many college level science courses are based on classroom teaching, but are enhanced by some form of Internet instruction.

Web enhanced teaching takes a variety of forms, ranging from a few items of information about the course to complete modules for online learning (eg, Riffell \& Sibley, 2005 for an introductory biology course). Course websites are expected to facilitate student access to study materials, reduce student reliance on handouts, and provide convenient tools (such as email and discussion groups) for communication among students, and between students and instructors. The prevalence of web enhanced teaching is increasing rapidly. For example, at Tel Aviv University (Israel), the number of courses that included Internet instruction increased from a handful to about 1000 (50\% of all courses) during 1998-2003. Only 1\% of these courses were completely online, while most remaining courses enhanced face to face teaching with a course website (Nachmias, 2002). Ninety five percent of the course websites were used for posting of study materials (such as lecture slides and reading materials), and one half of the websites were also used for course administration (posting of messages, grades, etc) (Nachmias et al., 2003).

As a further example, in a survey conducted at three universities in the UK, $67 \%$ of the responding lecturers reported that they delivered course material electronically, mainly reading material and lecture notes (Wilson, 2003). Thus, course websites have become the working standard for much of college teaching. Do students actually access the websites, even if the course structure does not require them to do so? If yes, what learning needs do websites facilitate?

In the present study we ask whether, and how, college students use course Internet sites to enhance their study. In particular, we investigate whether (a) the course websites are accessible to students; (b) students expect course websites to improve their achievement; (c) students primarily view course websites as sources of information or as tools for communication; (d) frequent use of the course websites correlates with higher achievements. 
Distance learning may reflect gender related differences in learning styles, as women may be under represented in online interactive learning, due to inferior levels of access and technology literacy, and dominant male behavior (Barrett \& Lally, 1999; Blum, 1999; Gunn et al., 2003). It has been suggested that women value social interaction while studying more highly than men, and may therefore use websites for communication, and social support, more frequently than men (Barrett \& Lally, 1999; Kirkup \& Von Prummer, 1990; King, 2000). In a traditional biology course female students accessed the course website more frequently than their male classmates (Sanders \& Morrison-Sheltar, 2001). A minor aim of our study was to assess whether gender differences in web enhanced learning also occurred in our sample of students, which contained $66 \%$ women.

Many studies evaluate distance learning programs by comparing student attitudes and achievement in classes that receive face to face instruction versus distance learning classes. Ideally, both classes are taught by the same instructor, with identical syllabi and study assignments (eg, King \& Hildreth, 2001; Tucker, 2001). Distance learning increased student and instructor satisfaction, and improved student achievements in some such studies (Shachar \& Neumann, 2003), but was as effective as classroom teaching in many others (eg, Russell, 1999; Ramage, 2002; Zeiler, 2003; Mottarella et al., 2004). The drawback in the design of these studies is that the quality of instruction may differ between the traditional and the distance learning class, due to the instructor's experience and/or preferences for the two teaching modes. In the present study, we tried to reduce this difficulty by focusing on the variation in the usage of Internet resources between students within the same course. Our investigation further differs from previous work by focusing on websites that augment traditional classroom teaching, rather than replacing it. We attempt to identify components of course websites that are most useful to the students taking the course, based on student reports and monitoring of website usage.

\section{Methods}

\section{Students and courses}

Ninety six students participated in the study in 2002-2003. Fifty two of them were first year students, and the remaining 44 were second year students, all majoring in biology. Background data on the student sample, based on their statements in pre-course questionnaires, are provided in Table 1.

The first year students took a course in Invertebrate Zoology. The second year students took a course in Introductory Ecology. Both courses included 
a weekly lecture and either laboratories or exercise sections. All courses were taught by the same instructor, and were accompanied by Internet sites. The language of instruction was Hebrew.

Table 1: Characteristics of the students who participated in the study $(n=72)$, based on pre-course questionnaires. Mean values are listed with their standard errors.

\begin{tabular}{|l|c|c|c|}
\cline { 2 - 3 } & \multicolumn{2}{|c|}{ Students who entered college in } & All \\
\cline { 2 - 3 } & 2002 & 2003 & students \\
\hline Sample size & 44 & 52 & 96 \\
\hline Percent men & 38 & 30 & 34 \\
\hline Age & $23.55 \pm 0.41$ & $22.33 \pm 0.32$ & $22.90 \pm 0.26$ \\
\hline College entrance examination score & $596.73 \pm 11.84$ & $604.00 \pm 12.71$ & $599.89 \pm 8.61$ \\
\hline Percent born in Israel & 75.7 & 78.8 & 77.1 \\
\hline $\begin{array}{l}\text { Percent with one college educated } \\
\text { parent }\end{array}$ & 17.6 & 25.0 & 19.4 \\
\hline $\begin{array}{l}\text { Percent with two college educated } \\
\text { parents }\end{array}$ & 44.1 & 25.0 & 33.9 \\
\hline
\end{tabular}

* A standard national exam, which is required for college admission in Israel. Scores range $400-800$.

\section{Course websites}

The course websites contained the following study materials: course syllabus, lecture slides, laboratory manual or exercise questions, sample exams or quizzes, review questions, and links to course related websites elsewhere. Some of the items on the websites were required for the course, while other items were not compulsory, but could be used as enrichment for interested students. The courses were designed so that students could complete them even if they did not use the websites at all. For example, there were no assignments that had to be submitted through the Internet sites. The websites also enabled written communication among students and between students and instructors in the course. The communication functions included discussion groups for the reading assignment and home assignments, options for online submission of assignments, and an email service provided by the learning management system. Additional communication channels in the courses included the face to face session, telephone and the regular college email platform.

\section{Monitoring website use}

The websites were implemented using the learning management system Highlearn [http:/ / www.britannica-ks.com/Products/Edu.asp]. Students were instructed in the use of Highlearn during the first week of each course. This system requires an individual login for each user, and allows the 
course instructor to monitor the usage of the website by individual students. The monitoring tool provides a list of course items accessed by each of the users, together with date and time of access. It also provides a record for each course item, which lists the dates and times of access to the item, and the identity of the users who accessed it. Using these data, we scored how many items each student in our sample accessed during the whole course period. We also divided the course items in the sites into groups (syllabi, lecture slides, discussion groups, etc), and recorded the total number of visits by students to each group of items.

\section{Questionnaires}

Questionnaires were administered to students in the first week of the course, and after the final exam. The students were not required to hand in the questionnaires. Introductory questionnaires (completed and returned by 72 students) contained questions on personal details, and about the students' expectations regarding web enhanced learning. Summary questionnaires contained questions regarding the students' use of the website during the course, and their attitudes towards it. Some of the questions are based on a questionnaire developed by Sanders \& MorrisonSheltar (2001). The questionnaires were validated by six independent experts, and were modified according to their comments. Students were asked to provide their names in both questionnaires, to enable individual comparisons between their attitudes, usage of the websites, and academic achievements. Forty four students returned the identified summary questionnaires. The use of identified questionnaires may have introduced biases in the students' responses. To test for this possibility, we asked 90 additional students, who took Invertebrate Zoology and Introductory Ecology in 2003-2004, to anonymously answer the same post-course questionnaire. Seventy four of the anonymous questionnaires were returned. We expected to reveal possible biases through differences between responses to identified and anonymous questionnaires.

\section{Results}

\section{Students' access to the Internet}

Fifty five percent $(55 \%)$ of the students in the study had access to the Internet from home. A further $30 \%$ accessed the Internet from the college computer classrooms, while the remaining $15 \%$ could access the Internet at the homes of friends or relatives. Only $20 \%$ of the respondents used the Internet daily. 


\section{Pre-course expectations and post-course attitudes}

At the beginning of the course, most of the students expected the website to increase their interest in the course subject. A lower proportion of respondents reported that the website enhanced their interest in the course topic in the post-course questionnaire. The difference between the distribution of pre-course and post-course attitudes on this issue was statistically significant (Table $2, \mathrm{chi}^{2}=18.09, \mathrm{df}=2, \mathrm{p}<0.01$ ). Similarly, the website affected the respondents' class attendance less than they expected at the beginning of the course. The difference between the distribution of pre-course and post-course student attitudes on this point was significant as well (Table $3, \mathrm{chi}^{2}=6.75, \mathrm{df}=2, \mathrm{p}<0.05$ ).

Table 2: Website effects on the students' interest in the course subject. Frequencies of questionnaire responses are reported. Sample sizes were 72 for pre-course questionnaires, and 118 for post-course questionnaires. We pooled identified $(n=44)$ and unidentified $(n=74)$ responses to the post-course questionnaires.

\begin{tabular}{|l|c|c|}
\hline & $\begin{array}{c}\text { Pre-course } \\
\text { expectation }\end{array}$ & $\begin{array}{c}\text { Post-course } \\
\text { statement }\end{array}$ \\
\hline Increased & 0.67 & 0.47 \\
\hline Unchanged & 0.33 & 0.53 \\
\hline Reduced & 0 & 0 \\
\hline
\end{tabular}

Table 3: Website effects on the students' tendency to attend lectures. Frequencies of questionnaire responses are reported. Sample sizes were 72 for pre-course questionnaires, and 118 for post-course questionnaires. We pooled identified $(n=44)$ and unidentified $(n=74)$ responses to the post-course questionnaires.

\begin{tabular}{|l|c|c|}
\hline & $\begin{array}{c}\text { Pre-course } \\
\text { expectation }\end{array}$ & $\begin{array}{c}\text { Post-course } \\
\text { statement }\end{array}$ \\
\hline Increased & 0.20 & 0.13 \\
\hline Unchanged & 0.77 & 0.87 \\
\hline Reduced & 0 & 0 \\
\hline
\end{tabular}

\section{Use of the website and academic achievements}

Ninety percent of the respondents expected the use of the website to improve their achievements in the course to a very large or large extent. We tested whether this expectation was fulfilled by recording the total number of visits to the website for all students. We then tested whether website usage correlated with the students' course grades. Contrary to the students' expectation, the correlation was not statistically significant $\left(r_{96}=0.12, p>0.05\right)$. We also found that students who did not visit the 
website at all $(\mathrm{n}=11)$ did not differ in their academic achievements from website users (students who accessed the website at least once during the course).

\section{Patterns of web site usage}

The websites were used frequently and regularly throughout the courses. The frequency of visits was $4.45 \pm 0.60$ (mean \pm SE) visits / student / week for Invertebrate Zoology, and $4.12 \pm 0.55$ visits / student/ week for Introductory Ecology. The students regarded the Internet sites as an important source of information (Figure 1). They reported that they used the websites mainly to access learning materials and course assignments. The records of items that were actually accessed validate the reports: lecture slides were accessed most frequently, followed by assignment sheets, review question sheets, and practice exams. The websites' communication possibilities (with other students and with the instructor) were hardly used at all.

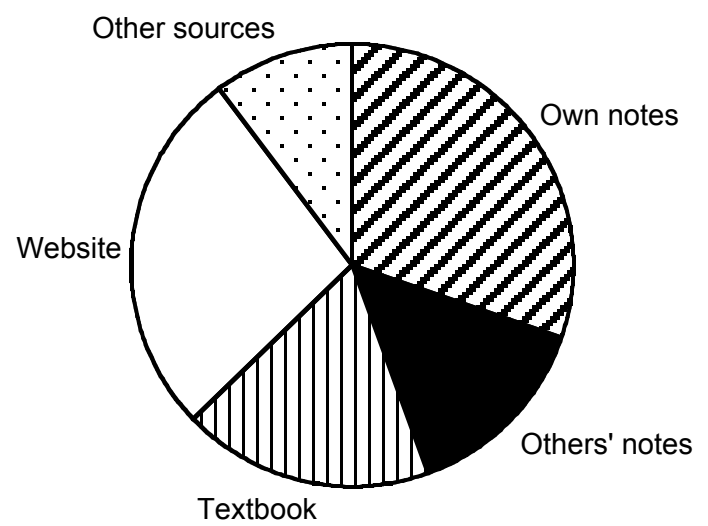

Figure 1: Relative importance of various sources of information, according to respondents' reports. Data are based on 44 identified and 74 anonymous responses.

\section{Gender effects}

The distribution of locations of Internet usage (home, college, friends, none) did not differ between men and women $\left(\mathrm{chi}^{2}=5.95, \mathrm{df}=3, \mathrm{p}>0.05\right)$. Gender differences were not found for the frequency of Internet usage $\left(\mathrm{chi}^{2}=10.68, \mathrm{df}=3, \mathrm{p}>0.05\right)$. Women had significantly higher pre-course expectations from the websites as compared to men (Table $4, \mathrm{chi}^{2}=16.89$, $\mathrm{df}=3, \mathrm{p}<0.01)$. However, usage records showed that men and women 
accessed the website at similar frequencies $\left(t_{58}=0.27, p>0.05\right)$. Males and females did not differ significantly in their course grades $\left(t_{68}=0.86, p>0.05\right)$. Both males and females regarded the websites mainly as sources of information: they were ranked most useful as sources of exercise forms, lecture slides, and course related Internet resources. The websites were considered least useful for student-student and student-instructor communication by both men and women.

Table 4: Male $(n=15)$ and female $(n=47)$ pre-course expectations regarding the importance of the website in improving their course achievements. Frequencies of questionnaire responses are reported.

\begin{tabular}{|l|c|c|}
\hline \multicolumn{1}{|c|}{ Response } & Male & Female \\
\hline Very important & 0.40 & 0.49 \\
\hline Important & 0.13 & 0.47 \\
\hline Somewhat important & 0.33 & 0.04 \\
\hline Unimportant & 0.14 & 0 \\
\hline
\end{tabular}

The students' questionnaire responses revealed a slight gender related difference in learning style. Both men (44\% of respondents) and women (47\% of respondents) stated that their preferred way of studying was taking notes in class. Men's second preferred mode of studying was listening to the lecture $(17 \%)$, while the women's second choice was studying the textbook ( $20 \%$ of respondents).

\section{Identified versus anonymous questionnaires}

The responses of the anonymous students (collected in 2003-4) were similar to the identified respondents (collected in 2002-3): About one half of the participants in both groups stated that the course website increased their interest in the course, and the majority of students in both groups reported that the website did not affect their class attendance. Students in both groups viewed their own lecture notes as their most important learning resource, followed by the course website. In both groups of students, the information content of the Internet sites, rather than their communication features, were considered important. The agreement between identified and anonymous replies suggests that identified responses can be regarded as reliable.

\section{Freestyle comments in the questionnaires}

The post-course questionnaires invited the students to comment on the Internet component of the courses, and in particular on problems associated with it. Nineteen participants responded. Eight respondents noted that they were not always able to log into the website. Three other 
users reported additional technical difficulties (difficulty obtaining a user name; slow response rate of the server). The remaining respondents commented that lectures slides were not accompanied by explanatory notes $(n=1)$; no solutions were provided to review questions $(n=2)$; learning materials were not updated frequently enough $(n=1)$, or did not match the lecture materials $(n=1)$; course related websites were not helpful $(n=1)$; printing of website materials was complicated or costly $(n=2)$; and that communication with the teaching staff via the website was difficult $(n=1)$. Thus, most responses addressed technical aspects of distance learning or the content of the posted learning materials. Only one comment dealt with the communication aspects of the website.

\section{Discussion}

Internet assisted instruction has become the standard in college level science education in recent years. The question is no longer whether lecturers ought to accompany their face to face teaching with websites, but how to do so most efficiently. It is time consuming to set up and maintain websites. Given that this large effort is almost expected in college level instruction, how can it be allocated most efficiently? What features of course websites are most useful to learners (these features should receive most attention during website development)? Which course objectives can be attained through the websites? Which objectives can be better attained in face to face sessions? Our study tried to address these questions for two course websites, used by a small sample of students, who also attended face to face classes. Despite the small scale of our study, we think that some insights can be gained from our results regarding effective development of web enhanced science courses:

- Students in our study visited the website regularly although they were not required to do so. They considered the website an important source of information, second only to lectures delivered by the course teacher. This suggests that the information contents of the websites are viewed as important learning resources by students, probably helping them to prepare for lectures and/or review lecture material. It is well worth the instructor's effort to maintain course website updates with respect to learning materials.

- Class attendance was not mandatory in the courses studied, and lecture materials were posted on the websites prior to each lecture.

Nevertheless, most students reported that the availability of learning materials did not decrease their tendency to attend lectures. We conclude that students perceived face to face instruction and e-learning as complementary, rather than interchangeable modes of learning. Face to face learning likely provided the social experience of learning, while 
the e-learning component provided opportunities for self paced study and review.

- Students did not use the website for communication with other students or with the instructor, presumably because they perceived face to face communication as easier and more effective. This trend emerges from the students' self-reports in the questionnaires, from the topics raised in their freestyle comments, and from their actual patterns of website usage. The development of written communication skills is explicitly defined as a learning goal in many distance education courses that are completely online. In traditional science courses, on the other hand, it is often not defined as a goal per se. It would therefore seem advisable for instructors to allocate more time to face to face communication with their students than to written communication via the course website in these circumstances.

Our results concur with many previous studies that report no significant effect of teaching technology on student's academic achievements (Russell, 1999). This is hardly surprising, because students did not differ in their exposure to face to face instruction, which comprised a major part of the course. Nevertheless, the course website increased interest in the course in about one half of the students, suggesting that this teaching technology may affect learners' attitudes.

In agreement with recent analyses of web based learning (Lu et al., 2003; Astleitner \& Steinberg, 2005), we found only few gender related differences in usage patterns of the websites or in achievement levels. Women did not report greater difficulties in accessing and using the websites than men. If anything, female students had higher initial expectations from the Internet technology as compared with male students. These findings contrast with some earlier studies, which found an under-representation of female students in Internet learning environments (Barrett \& Lally, 1999; Blum, 1999; Gunn et al., 2003).

A possible explanation for the difference between these findings and ours is that gender related differences usually surface in Internet forums and discussion groups. Women tend to value group study more highly than men (Kirkup \& von Prummer, 1990), but are often under-represented in online discussions (King, 2000). In our study, however, students met each other regularly, and did not utilise the Internet for group study and discussions. It seems likely that gender differences were more evident in the students' face to face interactions, as these provided their social learning environment. Zuga (1999) suggests that designers of e-learning environments ought to consider differences in learning styles between men and women to accommodate the needs of both genders. This 
recommendation does not seem to apply to web enhanced learning as described in our study, since male and female students seem to handle information retrieval from websites equally well.

Our study suggests that students regard course websites as important sources of information, but not as important means of communication. Obviously, student use of the website's communication functions can be enhanced if defined as course requirements. Such assignments can include compulsory participation in discussion groups, or in online collaborative projects. But does this kind of interaction provide any advantage over traditional group learning in science courses? Our subjective view is that the communication technology is not yet advanced enough to successfully replace traditional group study. An additional aspect of college level science education, which was not explored in our study, is the usage of public access Internet databases and software. The role of science course websites in directing students to these resources, and in training student to use them, is a promising topic for further research.

\section{Acknowledgements}

The study was supported by the MOFET Institute. Jay Hurvitz commented on the manuscript.

\section{References}

Allen, E. \& Seaman, J. (2003). Sizing the opportunity: The quality and extent of online education in the United States, 2002 and 2003. The Sloan Consortium. http: / / www.aln.org/resources/sizing_opportunity.pdf

Astleitner, H. \& Steinberg, R. (2005). Are there gender differences in web-based learning? An integrated model and related effect sizes. AACE Journal, 13(1), 4763. [verified 29 Nov 2005] http:/ / www.aace.org/ dl/ files / AACEJ/AACEJ13147.pdf

Barrett, E. \& Lally, V. (1999). Gender differences in an on-line learning environment. Journal of Computer Assisted Learning 15, 48-60.

Bates, A. W. (1999). The impact of new media on academic knowledge. Conference Proceedings "Akademie zum Dritten Jahrtausend", Munich, Germany. [verified 29 Nov 2005] http: / / bates.cstudies.ubc.ca/pdf/ knowledge.pdf

Blum, K. D. (1999). Gender differences in asynchronous learning in higher education: Learning styles, participation barriers and communication patterns. Journal of Asynchronous Learning Networks, 3(1). http: / / www.sloanc.org/publications/jaln/v3n1/v3n1_blum.asp

Fredericksen, A., Pickett, A. \& Shea, P. (2000). Student satisfaction and perceived learning with on-line courses: Principles and examples from the SUNY Learning Network. Journal of Asynchronous Learning Networks, 4(2). http: / / www.sloanc.org/publications / jaln/v4n2/v4n2_fredericksen.htm 
Guri-Rosenblit, S. (2003). Paradoxes and dilemmas in managing e-learning in higher education. Center for Studies in Higher Education. Paper CSHE7-03. [verified 29 Nov 2005] http:/ / repositories.cdlib.org/cshe/CSHE7-03

Gunn, C., McSporran, M., Macleod, H. \& French, S. (2003). Dominant or different? Gender issues in computer supported learning. Journal of Asynchronous Learning Networks, 7(1). http:/ / www.aln.org/publications/jaln/v7n1/v7n1_gunn.asp

King, L. (2000). Gender issues in online communities. Computer Professionals for Social Responsibility Newsletter, 18(1).

http:/ / www.cpsr.org/publications/newsletters/issues/2000/Winter2000/index.htm

King, P. \& Hildreth, D. (2001). Internet courses: Are they worth the effort? Journal of College Science Teaching, 31, 112-115.

Kirkup, G. \& von Prummer, C. (1990). Support and connectedness: The needs of women in distance education. Journal of Distance Education/ Revue de l'enseignement distance, 5(2). http:// cade.athabascau.ca/vol5.2/7_kirkup_and_von_prummer.html

Levenburg, N. M. \& Major, H.T. (1998). Distance learning: Implication for higher education in the 21st century. The Technology Source, November.

http: / / www.technologysource.org/article/distance_learning_implications_fo r_higher_education_in_the_21st_century / [verified 30 Nov 2005]

Lu, J., Yu, C-S. \& Liu, C, 2003. Learning style, learning patterns and learning performance in a WebCT-based MIS course. Information $\mathcal{E}$ Management, 40, 497507.

Mottarella, K., Fritzsche, B. \& Parrish, T. (2004). Who learns more? Achievement scores following web-based versus classroom instruction in psychology courses. Psychology Learning and Teaching, 4, 51-54.

Nachmias, R. (2002). A research framework for the study of a campus-wide webbased academic instruction project. The Internet and Higher Education, 5, 213-229.

Nachmias, R., Ram, J., Segev, L., Cohen, A., Amit, A. \& Azran, R. (2003). Online academic instruction at Tel Aviv University. Interim project report (in Hebrew).

Ramage, T. R. (2002). The "no significant difference" phenomenon: A literature review. E-journal of Instructional Science and Technology, 5. http; / / www.usq.edu.au/electpub/e-jist/docs/html2002/pdf/ ramage.pdf

Riffell, S. \& Sibley, D. (2005). Using web-based instruction to improve large undergraduate biology courses: An evaluation of a hybrid course format. Computers \& Education, 44, 217-235.

Russell, T. L. (1999). The No Significant Difference Phenomenon. Raleigh: North Carolina State University.

Sanders, D. W. \& Morrison-Shetlar, A. I. (2001). Student attitudes toward webenhanced instruction in an introductory biology course. Journal of Research on Computing in Education, 33(3), 251-262. 
Schifter, C.C. (2000). Compensation models in distance education. The Online Journal of Distance Learning Administration, 3(1). [verified 29 Nov 2005] http:/ / www.westga.edu/ distance/ schifter31.html

Shachar, M. \& Neumann, Y. (2003). Differences between traditional and distance education academic performances: A meta-analytic approach. International Review of Research in Open and Distance Education 4(2). [verified 30 Nov 2005] http:/ / www.irrodl.org/ content/v4.2/ shachar-neumann.html

Tucker, S. (2001). Distance education: Better, worse or as good as traditional education? Online Journal of Distance Learning Administration, 4(4). [verified 30 Nov 2005] http: / / www.westga.edu/ distance/ojdla/ winter44/ tucker44.html

US Department of Education, National Center for Education Statistics (1999). Distance education at post-secondary education institutions: 1997-8. By L. Lewis, K. Snow, E Farris, D. Levin \& B. Greene. Washington, DC. [verified 30 Nov 2005] http: / / nces.ed.gov/ pubs2000/2000013.pdf

Van Dusen, G. C. (1997). The virtual campus: Technology and reform in higher education. ASHE-ERIC Higher Education Report 25(5), Washington, DC: The George Washington University Graduate School of Education and Human Development Digest. [ERIC Digest, verified 30 Nov 2005] http:/ / www.ericdigests.org/1998-1/virtual.htm

Waits, T. \& Lewis, L. (2003). Distance education at degree-granting post-secondary institutions: 2000-2001. National Center for Education Statistics Report. [verified 30 Nov 2005] http:/ / nces.ed.gov/ pubsearch/ pubsinfo.asp?pubid=2003017

Wilson, R. (2003). E-education in the UK. Journal of Digital Information, 3(4). [verified 30 Nov 2005] http: / / jodi.ecs.soton.ac.uk/ Articles/v03/i04/Wilson

Zayler, G. (2003). Case study: The effectiveness of the online academic course "Project Management". MA thesis, Tel Aviv University, School of Education (In Hebrew, English Abstract).

Zuga, K. F. (1999). Addressing women's way of knowing to improve the technology education environment for all students. Journal of Technology Education, 10(2). http:/ / scholar.lib.vt.edu/ ejournals/JTE/v10n2/ pdf/ zuga.pdf

Tamar Keasar, Department of Life Sciences, Achva Academic College, POB Shikmim 79800, Israel. Corresponding author email: tkeasar@bgumail.bgu.ac.il

Rachel Baruch and Esther Grobgeld-Dahan, Achva College of Education, POB Shikmim 79800, Israel 